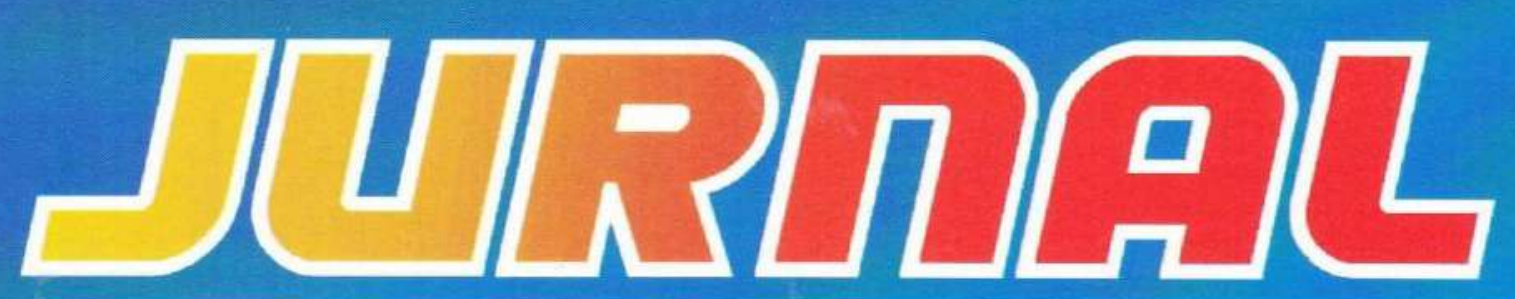

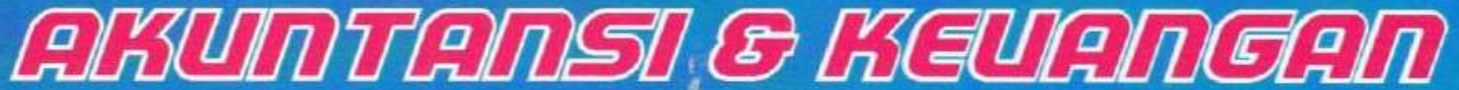

Volume 11, No. 1, Maret 2020

ISSN: $2087-2054$

Analisa Perbandingan Economic Value Added (EVA) Dan Return On Asset (ROA) Dalam Menilai Kinerja Perusahaan (Studi Kasus Pada Perusahaan Rokok Yang Terdaftar Di Bursa Efek Indonesiaperiode 2015-2018).

\section{Dewi Silvia}

Analisis Kinerja Anggaran Pendapatan Dan Belanja Daerah Pada Pemerintah Daerah Kabupaten Oku Periode 2013-2017

Hasiatul Aini, Mardiah Kenamon \& Yeni Anggraini

Analisis Kinerja Keuangan Pemerintah Daerah Oku Selatan Tahun Anggaran 2013-2017. Anis Feblin \& Yulitiawati

Pengaruh Economic Value Added (EVA) Dan Market Value Added (MVA) Terhadap Return Saham.

\section{Luke Suciyati Amna}

Analisis Rasio Keuangan Anggaran Pendapatan Dan Belanja Daerah Untuk Menilai Kinerja Keuangan Pemerintah Daerah Kabupaten Pesawaran Tahun 2010-2014.

\section{Herry Goenawan Soedarsa}

Pengaruh Kualitas Audit Dan Komite Audit Terhadap Kualitas Pelaporan Keuangan Perusahaan Yang Terdaftar Di Jakarta Islamic Index (JII).

\section{Liya Ermawati, Yulistia Devi \& Naurah Nazhifah Arramadani}




\section{JURNAL}

ARUNTANSI \& KEUANGAN

Volume 11, No. 1, Maret 2020

ISSN: $2087-2054$

Dewan Pembina

Dr. Ir. M. Yusuf S. Barusman, M.B.A

Dr. Andala Rama Putra Barusman, S.E., M.A.Ec.

Penanggung Jawab

Aminah, S.E., M.S.Ak

Pimpinan Redaksi

Dr. Haninun, S.E., M.S.Ak

Sekretaris Redaksi

Riswan, S.E., M.S.Ak

Luke Suciyati Amna, S.E., M.S.Ak

\section{Penyuting Ahli (Mitra Bestari)}

Tina Miniawati, S.E., M.B.A. (Universitas Trisakti)

Dr. Khomsiyah, S.E., M.M. (Universitas Trisakti)

Dr. Lindrianasari, S.E., M.Si.Akt., C.A. (Universitas Lampung)

Sujoko Efferin, Mcom (Hons), MA(Econ), Ph.D. (Universitas Surabaya)

\section{Penerbit}

Universitas Bandar Lampung

Fakultas Ekonomi dan Bisnis Program Studi Akuntansi

SENARAI-Jurnal Akuntansi \& Keuangan Terbit 2 kali setahun pada bulan Maret \&

September

Artikel yang dimuat berupa hasil riset Empiris dan telaah teoritis konsepsual yang kritis dalam kajian bidang akuntansi, auditing, perpajakan, dan keuangan.

\section{Alamat Redaksi}

Gedung G- Program Studi Akuntansi Fakultas Ekonomi dan Bisnis

Universitas Bandar Lampung

Kampus A Jalan Z.A Pagar Alam No. 26 Labuan Ratu Bandar Lampung 35142

Telp: (0721) 701979, Fax: (0721) 701467, Email: Prodi.akuntansi@ubl.ac.id 


\section{AKUNTANSI \& KEUANGAN}

Analisa Perbandingan Economic Value Added (EVA) Dan Return On Asset (ROA) Dalam Menilai Kinerja Perusahaan (Studi Kasus Pada Perusahaan Rokok Yang Terdaftar Di Bursa Efek Indonesiaperiode 2015-2018).

\section{Dewi Silvia}

Analisis Kinerja Anggaran Pendapatan Dan Belanja Daerah Pada Pemerintah Daerah Kabupaten Oku Periode 2013-2017

Hasiatul Aini, Mardiah Kenamon \& Yeni Anggraini

Analisis Kinerja Keuangan Pemerintah Daerah Oku Selatan Tahun Anggaran 2013-2017. Anis Feblin \& Yulitiawati

Pengaruh Economic Value Added (EVA) Dan Market Value Added (MVA) Terhadap Return Saham.

\section{Luke Suciyati Amna}

Analisis Rasio Keuangan Anggaran Pendapatan Dan Belanja Daerah Untuk Menilai Kinerja Keuangan Pemerintah Daerah Kabupaten Pesawaran Tahun 2010-2014.

\section{Herry Goenawan Soedarsa}

Pengaruh Kualitas Audit Dan Komite Audit Terhadap Kualitas Pelaporan Keuangan Perusahaan Yang Terdaftar Di Jakarta Islamic Index (JII).

Liya Ermawati, Yulistia Devi \& Naurah Nazhifah Arramadani 


\section{JURNAL}

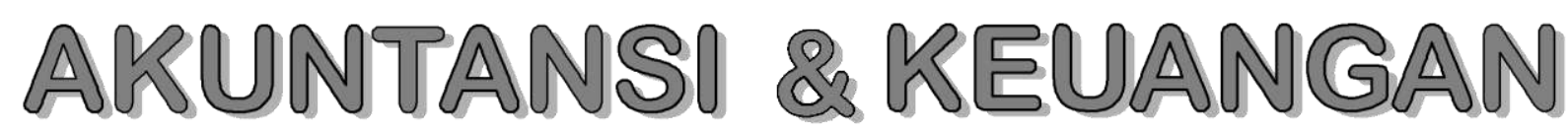

Volume 11, No. 1, Maret 2020

ISSN: $2087-2054$

Daftar Isi

Halaman

Analisa Perbandingan Economic Value Added (EVA) Dan Return On Asset (ROA) Dalam Menilai Kinerja Perusahaan (Studi Kasus Pada

Perusahaan Rokok Yang Terdaftar Di Bursa Efek Indonesiaperiode 2015-2018).

Dewi Silvia

Analisis Kinerja Anggaran Pendapatan Dan Belanja Daerah Pada

Pemerintah Daerah Kabupaten Oku Periode 2013-2017

18-34

Hasiatul Aini, Mardiah Kenamon \& Yeni Anggraini

Analisis Kinerja Keuangan Pemerintah Daerah Oku Selatan Tahun Anggaran 2013-2017.

$35-58$

Anis Feblin \& Yulitiawati

Pengaruh Economic Value Added (EVA) Dan Market Value Added (MVA)

Terhadap Return Saham.

$59-73$

Luke Suciyati Amna

Analisis Rasio Keuangan Anggaran Pendapatan Dan Belanja Daerah Untuk Menilai Kinerja Keuangan Pemerintah Daerah Kabupaten

Pesawaran Tahun 2010-2014.

Herry Goenawan Soedarsa

Pengaruh Kualitas Audit Dan Komite Audit Terhadap Kualitas Pelaporan

Keuangan Perusahaan Yang Terdaftar Di Jakarta Islamic Index (JII).

$92-111$

Liya Ermawati, Yulistia Devi \& Naurah Nazhifah Arramadani 


\section{JURNAL \\ AKUNTANSI \& KEUANGAN}

Volume 11, No. 1, Maret 2020

ISSN: 2087-2054

\section{Informasi Kebijakan dan Selingkung Berkala}

\section{Kebijakan editorial}

JURNAL Akuntansi \& Keuangan adalah sebuah berkala yang dipublikasikan oleh Universitas Bandar Lampung, yang bertujuan untuk menjadi wadah kreatifitas para akademisi, profesional, peneliti, dan mahasiswa di bidang Akuntansi dan Keuangan termasuk juga bidang Auditing, Sistem Informasi Akuntansi, Tata kelola Perusahaan, Perpajakan, Akuntansi Internasional, Akuntansi Managemen, Akuntansi Keperilakuaan, Pasar Modal dan lain sebagainya. Topik yang semakin meluas di bidang kajian riset Akuntansi diakomodir publikasinya di dalam berkala ini.

Paper yang akan dipublikasikan di dalam berkala JURNAL Akuntansi \& Keuangan harus ditulis di dalam bahasa Indonesia yang baik dan sesuai dengan EYD. Semua instrumen yang digunakan untuk memperoleh data penelitian harus dimasukkan di dalam lampiran paper penelitian, paling tidak, penulis bersedia memberikan klarifikasi atas instrumen yang digunakan saat ada permintaan dari peneliti lainnya.

\section{Sekretariat Editor Berkala}

Gedung F - Fakultas Ekonomi Universitas Bandar Lampung

Fakultas Ekonomi Program Studi Akuntansi

Kampus A Jalan Z.A. Pagar Alam No. 26 Labuhan Ratu Bandar Lampung 35142

Telp.: (0721) 701979, Fax.: (0721) 701467, Email:

\section{Petunjuk penulisan}

Artikel yang dikirim ke JURNAL Akuntansi \& Keuangan harus mengikuti petunjuk seperti berikut:

1. Naskah merupakan naskah asli yang belum pernah diterbitkan atau sedang dilakukan penilaian pada berkala lain. Naskah ditulis dalam bahasa Indonesia dengan jarak 1 spasi, sepanjang 20-30 halaman kertas A4 dengan tipe huruf Times New Roman.. Naskah dikirim atau diserahkan ke sekretariat JURNAL Akuntansi \& Keuangan rangkap satu disertai disket berikut dengan biodata penulis dan alamat lengkap (kantor dan rumah) pada lembaran yang terpisah dari halaman pertama artikel.

2. Judul naskah dapat ditulis dengan menggambarkan isi pokok tulisan, dan atau ditulis secara ringkas, jelas, dan menarik.

3. Nama Penulis disertai catatan kaki tentang profesi dan lembaga tempat penulis bekerja dalam naskah yang telah diterima untuk diterbutkan.

4. Abstrak ketik satu spasi, tidak lebih dari 250 kata dalam bahasa Inggris. Abstrak memuat tujuan penelitian, isu, permasalahan, sampel dan metode penelitian, serta hasil dan simpulan (jika memungkinan). 
5. Pendahuluan beriksikan uraian tentang latar belakang masalah, ruang lingkup penelitian, dan telaah pustaka yang terkait dengan permasalahan yang dikaji, serta rumusan hipotesis (jika ada). Uraian pendahuluan maksimum $10 \%$ total halaman.

6. Untuk penelitian kuantitatif,

a. Telaah Literatur dan Pengembangan Hipotesis memuat paling tidak satu buah teori yang menjadi dasar pemikiran penelitian. Hipotesis dikembangkan menggunakan asumsi dasar teori dan hasil penelitian sebelumnya. Telah literatur maksimum $40 \%$ total halaman.

b. Metodologi Penelitian meliputi uraian yang rinci tentang bahan yang digunakan, metoda yang dipilih, teknik, dan cakupan penelitian. Uraian bahan dan metoda maksimum $20 \%$ total halaman.

7. Untuk penelitian kualitatif menyesuaikan dengan metodologi kualitatif.

8. Hasil dan Pembahasan merupakan uraian obyektif dari-hasil penelitian dan pembahasan dilakukan untuk memperkaya makna hasil penelitian. Uraian hasil dan pembahasan minimum $25 \%$ total halaman.

9. Simpulan yang merupakan rumusan dari hasil-hasil penelitian. Harus ada sajian dalam satu kalimat inti yang menjadi simpulan utama. Simpulan maksimum $10 \%$ dari keseluruhan lembar artikel.

10. Referensi (Daftar Pustaka) ditulis berurutan berdasarkan alphabetical, disusun menggunakan suku kata terakhir dari nama penulisnya, atau institusi jika dikeluarkan oleh organisasi.

a. Buku: nama penulis, tahun penerbitan, judul lengkap buku, penyunting (jika ada), nama penerbit, dan kota penerbitan.

b. Artikel dalam buku: nama penulis, tahun penerbitan, judul artikel/tulisan, judul buku, nama penyunting, kota penerbitan, nama penerbit, dan halaman.

c. Terbitan berkala: nama penulis, tahun penerbitan, judul tulisan, judul terbitan (bila disingkat, sebaiknya menggunakan singkatan yang baku), volume, nomor, dan halaman.

d. Artikel dalam internet: nama penulis, judul, dan situsnya.

e. Tabel diberi nomor dan judul dilengkapi dengan sumber data yang ditulis dibawah badan tabel, diikuti tempat dan waktu pengambilan data.

f. Ilustrasi dapat berupa gambar, grafik, diagram, peta, dan foto diberi nomor dan judul.

11. Setiap referensi yang digunakan di dalam naskah artikel menggunakan petunjuk yang dirujuk pada The Indonesian Journal of Accounting Research, sebagai berikut:

A. Kutipan dalam tubuh naskah paper harus disesuaikan dengan contoh berikut:

I. Satu sumber kutipan dengan satu penulis (Brownell, 1981).

II. Satu sumber kutipan dengan dua penulis (Frucot dan Shearon, 1991).

III. Satu sumber kutipan dengan lebih dari satu penulis (Hotstede et al., 1990).

IV. Dua sumber kutipan dengan penulis yang berbeda (Dunk, 1990; Mia, 1988).

V. Dua sumber kutipan dengan satu penulis (Brownell, 1981, 1983).

VI. Dua sumber kutipan dengan satu penulis diterbitkan pada tahun yang sama (Brownell, 1982a, 1982b).

VII. Sumber kutipan dari lembaga harus dinyatakan dengan menggunakan akronim institusi (FASB, 1994)

B. Setiap artikel harus menulis referensi menggunakan panduan berikut:

I. Referensi harus tercantum dalam urutan abjad dari nama belakang penulis atau nama lembaga. 
II. Referensi harus dinyatakan dengan urutan sebagai berikut: penulis (s) nama, tahun publikasi, judul kertas atau buku teks, nama jurnal atau penerbit dan nomor halaman. Contoh:

a) Amerika Akuntansi Association, Komite Konsep dan Standar Laporan Keuangan Eksternal. 1977. Pernyataan tentang Teori Akuntansi dan Teori Penerimaan. Sarasota, FL: AAA.

b) Demski, J. S., dan D. E. M. Sappington. 1989. Struktur hirarkis dan akuntansi pertanggungjawaban, Jurnal Akuntansi Penelitian 27 (Spring): 40-58.

c) Dye, R. B., dan R. Magee. 1989. Biaya Kontijensi untuk perusahaan audit. Kertas kerja, Northwestern University, Evansto, IL.

d) Indriantoro, N. 1993. Pengaruh Penganggaran Partisipatif Terhadap Prestasi Kerja dan Kepuasan Kerja dengan Locus of Control dan Dimensi Budaya sebagai Moderating Variabel. Ph.D. Disertasi. University of Kentucky, Lexington.

e) Naim, A. 1997. Analisis Penggunaan Akuntansi Biaya Produk Dalam Keputusan Harga oligopolistik. Jurnal Ekonomi Dan Bisnis Indonesia 12 (3): 43-50.

f) Porcano, T. M. 1984a. Keadilan distributif dan Kebijakan Pajak. Akuntansi Ulasan 59 (4): 619-636.

g) --------. 1984b. Pengaruh Persepsi Kebijakan Pajak Niat Investasi Perusahaan. The Journal of American Association Perpajakan 6 (Fall): 719.

h) Pyndyk, R. S. dan D. L. Rubinfield. 1987. Model ekonometrik \& Forecasts Ekonomi, 3rd ed. NY: McGraw-Hill Publishing, Inc.

12. Author(s) harus melampirkan CV, alamat email, alamat korespondensi dan pernyataan yang menyatakan pasal tersebut tidak sedang disampaikan kepada atau diterbitkan oleh jurnal lain dalam email tersebut dan /atau pos. 
Halaman $74-91$

\title{
ANALISIS RASIO KEUANGAN ANGGARAN PENDAPATAN DAN BELANJA DAERAH UNTUK MENILAI KINERJA KEUANGAN PEMERINTAH DAERAH KABUPATEN PESAWARAN TAHUN 2010-2014
}

\author{
Herry Goenawan Soedarsa* \\ (Dosen Tetap Fakultas Ekonomi dan Bisnis Universitas Bandar Lampung) \\ Email: $\underline{\text { Herry.gs13@gmail.com. }}$
}

\begin{abstract}
This study aims to assess the financial performance of the local government district Pesawaran using financial ratio analysis of budget revenue and expenditure Pesawaran District 2010-2014.

The analysis is used to analyze financial performance is by calculating the ratio of the area Independence, Ratio Effectiveness, Efficiency Ratio. While the analysis is used to analyze the financial capacity of the area is by counting Share and Growth, Financial Capability Map. Based on analysis of the financial performance of it can be concluded, the average ratio of local independence Pesawaran District that are in the relationship patterns instructive. But the level of effectiveness of financial management Pesawaran District is fairly effective. While the level of efficiency of financial management is relatively less efficient, the financial condition of local government district Pesawaran still not ideal. Can be seen from the average Share and Growth. Position Pesawaran District is in quadrant II.
\end{abstract}

Keywords: Financial Ratio Analysis Budgets, Performance Local Government Finance

\section{Pendahuluan}

Dalam melaksanakan tugas dan fungsi Pemerintah Daerah sebagaimana dimaksud dalam pasal 21 dan 22 Undang-Undang Nomor 32 tahun 2004 tentang Pemerintah Daerah menegaskan fungsi perencanaan yang dijabarkan dalam bentuk pendapatan dan pembiayaan belanja daerah yang dikelola dalam sistem pengelolaan keuangan daerah yang efisien, efektif, transparan, akuntabel, tertib, adil, patuh dan taat pada peraturan perundang-undangan.

Laporan keuangan pemerintah daerah dibuat sesuai dengan Peraturan Pemerintah Republik Indonesia Nomor 71 Tahun 2010 Tentang Standar Akuntansi Pemerintahan. Laporan keuangan disajikan secara sederhana agar mudah dipahami. Meskipun laporan keuangan sudah bersifat general purposive yaitu bersifat umum dan sederhana. Tetapi tidak semua kepala 
daerah dapat memahami akuntansi yang merupakan alat untuk menghasilkan laporan keuangan sementara informasi tersebut sangat dibutuhkan dalam pengambilan keputusan. Sehingga untuk mempermudah dalam memahami dan menginterpretasikan laporan keuangan tersebut dapat dibantu menggunakan analisis laporan keuangan.

Analisis rasio keuangan terhadap Anggaran Pendapatan dan Belanja Daerah dilakukan dengan mengitung Rasio Kemandirian, Rasio Efektifitas, Rasio Efisiensi. Sedangkan untuk menghitung kemampuan keuangan daerah, yaitu dengan cara menghitung Share dan Growth.

Berdasarkan latar belakang diatas maka rumusan masalah penelitian berikut: bagaimana kinerja keuangan Kabupaten Pesawaran berdasarkan analisis rasio keuangan pada APBD. Adapun tujuan dari penelitian ini adalah mengetahui kinerja keuangan daerah berdasarkan analisis rasio keuangan pada APBD Kabupaten Pesawaran.

\section{Tinjauan Pustaka}

Laporan keuangan merupakan instrumen penting bagi pemerintah untuk menunjukan transparansi dan akuntabilitas (Mahmudi, 2011). transparansi memiliki arti keterbukaan organisasi dalam memberikan informasi yang terkait dengan aktivitas pengelolaan sumberdaya publik kepada pihak-pihak yang menjadi pemangku kepentingan. Transparansi juga berati adanya penjelasan manajemen organisasi sektor publik mengenai aktivitas, program dan kebijakan yang sudah, sedang, dan akan dilakukan beserta sumberdaya yang akan digunakanya sebagai upaya mewujudkan transparansi publik. Transparansi pengelolaan keuangan publik merupakan prinsip Good Governance yang harus dipenuhi oleh organisasi sektor publik. Dengan dilakukanya transparansi tersebut publik akan memperoleh informasi yang aktual dan faktual, sehingga mereka dapat menggunakan informasi tersebut untuk (Mahmudi, 2010):

1. Membandingkan kinerja keuangan yang dicapai dengan yang direncanakan (realisasi vs anggaran).

2. Menilai ada tidaknya unsur korupsi dan manipulasi dalam perencanaan, pelaksanaan dan pertanggungjawaban anggaran.

3. Menentukan tingkat kepatuhan terhadap peraturan perundang-undangan yang terkait.

4. Mengetahui hak dan kewajiban masing-masing pihak, yaitu antara manajemen organisasi sektor publik dengan masyarakat dan dengan pihak lain yang terkait. 
Akuntabilitas merupakan kewajiban pemegang amanah (agent) untuk memberikan pertanggungjawaban, menyajikan, melaporkan, dan mengungkapkan segala aktivitas dan kegiatan yang menjadi tanggungjawabnya kepada pihak pemberi amanah (principal) yang memiliki hak dan kewenangan untuk meminta pertanggungjawaban tersebut. Dalam melakukan akuntabilitas publik, organisasi sektor publik berkewajiban untuk memberikan informasi sebagai bentuk pemenuhan hak-hak publik. Hak-hak publik itu antara lain (Mardiasmo,2010):

1. Hak untuk tahu (right to know).

2. Hak untuk diberi informasi (right to be informed).

3. Hak untuk didengar aspirasinya (right to be heard and to be listened to).

Organisasi sektor publik dituntut untuk tidak sekedar melakukan akuntabilitas vertikal (vertical accountability), yaitu pelaporan kepada atasan, akan tetapi juga melakukan akuntabilitas horizontal (horizontal accountability). Yaitu pelaporan kepada masyarakat luas.

\section{Pelaporan Keuangan}

Menurut Government Accounting Standard Board (GASB,1998), pelaporan keuangan bukan merupakan tujuan akhir, tetapi dimaksudkan untuk memberikan informasi yang berguna untuk :

1. Membantu memenuhi kewajiban pemerintah untuk menjadi akuntabel terhadap publik.

2. Membantu memenuhi kebutuhan para pengguna laporan yang mempunyai keterbatasan kewenangan, keterbatasan kemampuan atau sumber daya untuk memperoleh informasi dan oleh sebab itu mereka menyandarkan pada laporan sebagai sumber informasi penting. Untuk tujuan tersebut, pelaporan keuangan harus mempertimbangkan kebutuhan para pengguna dan keputusan yang mereka buat. Laporan keuangan yang disampaikan setidaknya meliputi :

a) Laporan Realisasi APBD

b) Neraca

c) Laporan Arus Kas

d) Catatan Atas Laporan Keuangan

Laporan keuangan merupakan instrumen penting bagi pemerintah untuk menunjukan transparansi dan akuntabilitas. Terdapat dua alasan mengapa pemerintah perlu mempublikasikan laporan keuangan yaitu (Mahmudi, 2011):

1. laporan keuangan merupakan alat pengendalian manajemen dan evalusi kinerja bagi pemerintah secara keseluruhan maupun unit-unit kerja di dalamnya.

2. Laporan keuangan merupakan bentuk pertanggungjawaban manajemen kepada pihak internal (internal accountability), yaitu kepada pihak-pihak 
di dalam organisasi, misalnya atasan, pegawai, dan pemeriksa maupun pertnggungjawaban eksternal (external accountability). Kepada pihakpihak luar yang berkepentingan, misalnya masyarakat, investor, kreditor, lembaga donor, pers, serta pihak-pihak lain yang berkepentingan dengan laporan tersebut untuk dasar pengambilan keputusan ekonomi, sosial, dan politik.

\section{Tujuan Penyajian Laporan Keuangan}

Dalam Peraturan Pemerintah Republik Indonesia Nomor 71 Tahun 2010 Tentang Standar Akuntansi Pemerintahan, laporan keuangan disusun dengan tujuan memberikan informasi yang relevan mengenai posisi keuangan dan transaksi selama satu periode pelaporan. Laporan keuangan digunakan untuk membandingkan beberapa hal seperti: realisasi pendapatan, belanja, transfer, dan pembiayaan dengan anggaran yang telah ditetapkan, menilai kondisi keuangan, mengevaluasi entitas pelaporan, serta membantu menentukan ketaatan terhadap perundang-undangan. Suatu entitas mempunyai kewajiban untuk melaporkan upaya-upaya yang telah dilakukan dalam pencapaian targetnya serta seberapakah hasil yang telah dicapai oleh entitas pada suatu periode pelaporan keuangan yang bertujuan untuk beberapa kepentingan:

1) Akuntabilitas

Mempertanggung jawabkan pengelolaan sumber daya serta pelaksanaan kebijakan yang dipercayakan kepada entitas pelaporan dalam mencapai tujuan yang telah ditetapkan secara periodik.

2) Manajemen

Membantu mengevaluasi pelaksanaan kegiatan suatu entitas pelaporan dalam periode pelaporan.

3) Transparansi

Memberikan informasi keuangan yang terbuka dan jujur kepada masyarakat.

4) Keseimbangan Antargenerasi (Intergenerational Equity)

Membantu mengetahui kecukupan penerimaan pemerintah pada periode pelaporan untuk membiayai pengeluaran yang dialokasikan dan apakah generasi yang akan datang akan ikut menanggung beban pengeluaran tersebut.

Secara garis besar tujuan penyajian laporan keuangan sektor publik adalah (Mahmudi, 2011):

1. Memberikan informasi kepada para pengguna laporan keuangan yang digunakan untuk pertimbangan pembuatan keputusan ekonomi, sosial, dan politik.

2. Menunjukan transparansi dan akuntabilitas publik. 
3. Memberikan informasi untuk evaluasi kinerja manajerial dan organisasi.

Tujuan pelaporan keuangan menurut Peraturan Pemerintah No 71 Tahun 2010 tentang standar akuntansi pemerintahan. Kerangka konseptual akuntansi pemerintahan yang merupakan salah satu bagian dari standar akuntasnsi pemerintahan, dijelaskan mengenai tujuan pelaporan keuangan pemerintah. Pelaporan keuangan pemerintah seharusnya menyajikan informasi yang bermanfaat bagi para pengguna dalam menilai akuntabilitas dan membuat keputusan baik dalam ekonomi, sosial, maupun politik dengan (Mahmudi, 2011):

a. Menyediakan informasi tentang sumber, alokasi, dan penggunaan sumber daya keuangan.

b. Menyediakan informasi mengenai kecukupan penerimaan periode berjalan untuk membiayai seluruh pengeluaran.

c. Menyediakan informasi mengenai jumlah sumber daya ekonomi yang digunakan dalam kegiatan entitas pelaporan serta hasil yang telah dicapai.

d. Menyediakan informi menganai bagaimana entitas pelaporan mendanai seluruh kegiatanya dan mencukupi kebutuhan kasnya.

e. Menyediakan informasi mengenai posisi keuangan dan kondisi entitas pelaporan berkaitan dengan sumber-sumber penerimaannya, baik jangka pendek maupun jangka panjang, termasuk yang berasal dari pungutan pajak dan pinjaman.

f. Menyediakan informasi mengenai perubahan posisi keuangan entitas pelaporan, apakah mengalami kenaikan atau penurunan, akibat dari kegiatan yang dilakukan selama periode pelaporan.

\section{Anggaran Pendapatan dan Belanja Daerah (APBD)}

Menurut Undang-Undang No. 32 Tahun 2004 Tentang Pemerintahan Daerah dan Undang-Undang No. 33 Tahun 2004 Tentang Perimbangan Keuangan Pusat dan Daerah, yang dimaksud dengan Anggaran Pendapatan dan Belanja Daerah (APBD) adalah rencana keuangan tahunan pemerintah daerah yang dibahas dan disetujui bersama oleh pemerintah daerah dan DPRD, dan ditetapkan dengan peraturan daerah.

Berdasarkan Undang-Undang No. 33 Tahun 2004 Tentang Perimbangan Keuangan Pusat dan Daerah pasal 66 ayat 3, Anggaran Pendapatan Belanja Daerah (APBD) memiliki fungsi sebagai berikut:

1. Fungsi Otorisasi. Artinya bahwa anggaran daerah menjadi dasar untuk melaksanakan pendapatan dan belanja pada tahun yang bersangkutan.

2. Fungsi Perencanaan. Artinya bahwa anggaran daerah menjadi pedoman bagi menajemen dalam merencanakan kegiatan pada tahun yang bersangkutan. 
3. Fungsi Pengawasan. Artinya bahwa anggaran daerah menjadi pedoman untuk menilai apakah kegiatan penyelanggaraan pemerintahan sesuai dengan ketentuan yang telah ditetapkan.

4. Fungsi Alokasi. Artinya bahwa angaran daerah untuk mengurangi pengangguran dan pemborosan sumber daya, serta meningkatkan efisiensi dan efektifitas perekonomian.

Berdasarkan Permendagri No. 21 Tahun 2011, struktur atau komponen APBD sebagai berikut:

1. Pendapatan Pemerintah Daerah sebagaimana dimaksud dalam UndangUndang No. 33 Tahun 2004 pasal 22 ayat (1) huruf a meliputi semua penerimaan uang melalui rekening kas umum daerah, yang menambah ekuitas dana, merupakan hak daerah dalam satu tahun anggaran dan tidak perlu dibayar kembali oleh daerah. Pendapatan daerah dikelompokkan atas:

a. Pendapatan Asli Daerah.

b. Pajak Daerah.

c. Retribusi Daerah.

d. Hasil Pengelolaan Kekayaan Daerah Yang Dipisahkan.

e. Pendapatan lain Asli Daerah Yang Sah.

f. Dana Perimbangan.

g. Dana Bagi Hasil bersumber dari pajak dan sumber daya alam.

h. Dana Alokasi Umum.

i. Dana Alokasi Khusus.

\section{Kinerja keuangan Pemerintah daerah}

Menurut (Syamsi,1986) kinerja keuangan daerah adalah kemampuan suatu daerah untuk menggali dan mengelola sumber-sumber keuangan asli daerah dalam memenuhi kebutuhannya guna mendukung berjalannya sistem pemerintahan, pelayanan kepada masyarakat dan pembangunan daerahnya dengan tidak tergantung sepenuhnya kepada pemerintah pusat dan mempunyai keleluasaan didalam menggunakan dana-dana untuk kepentingan masyarakat daerah dalam batas-batas yang ditentukan peraturan perundang-undangan.

Pengukuran kinerja keuangan pemerintah daerah dilakukan untuk memenuhi 3 tujuan yaitu (Mardiasmo,2002):

1. Memperbaiki kinerja pemerintah.

2. Membantu mengalokasikan sumber daya dan pembuatan keputusan.

3. mewujudkan pertanggungjawaban publik dan memperbaiki komunikasi dan kelembagaan. 
Tujuan sistem pengukuran kinerja menurut (Ihyahul, dalam muhibtari,2009), antara lain adalah sebagai berikut:

1. Untuk mengkomunikasikan strategi secara lebih baik.

2. Untuk mengukur kinerja finansial dan non-finansial secara berimbang sehingga dapat ditelusur perkembangan pencapaian strategi.

3. Untuk mengakomodasi pemahaman kepentingan manajer level menengah dan bawah serta memotivasi untuk mencapai goal congcruence.

4. Sebagai alat untuk mencapai kepuasan berdasarkan pendekatan individual dan kemampuan kolektif yang rasional.

Manfaat sistem pengukuran kinerja menurut (Ihyahul, dalam muhibtari,2009), antara lain adalah sebagai berikut:

1. Memberikan pemahaman mengenai ukuran yang digunakan untuk menilai kinerja manajemen.

2. Memberikan arah untuk mencapai target kinerja yang telah ditetapkan.

3. Untuk memonitor dan mengevaluasi pencapaian kinerja dan membandingkan dengan target kinerja serta melakukan tindakan korektif untuk memperbaiki kinerja.

4. Sebagai dasar untuk memberikan penghargaan dan hukuman (reward \& punishment) secara Objektif atas pencapaian prestasi yang diukur sesuai dengan sistem pengukuran kinerja yang telah disepakati.

5. Sebagai alat komunikasi antara bawahan dan pimpinan dalam rangka memperbaiki kinerja organisasi.

6. Membantu mengidentifikasi apakah kepuasan pelanggan sudah terpenuhi.

7. Membantu memahami proses kegiatan instansi pemerintah.

8. Memastikan bahwa pengambilan keputusan dilakukan secara objektif.

\section{Analisis Rasio Keuangan pada APBD}

Dalam rangka pengelolaan keuangan daerah yang transparan, jujur, demokratis, efektif, efisien, dan akuntabel, analisis rasio terhadap APBD perlu dilaksanakan. Hasil analisis rasio tersebut dapat digunakan untuk (Halim,2008):

1. Menilai kemandirian keuangan daerah dalam membiayai penyelenggaraan otonomi daerah;

2. Mengukur efisiensi Pemerintah Daerah dalam merealisasikan pendapatan daerah;

3. Mengukur sejauh mana efektifitas Pemerintah Daerah dalam membelanjakan pendapatan daerahnya;

4. Mengukur kontribusi masing-masing sumber pendapatan dalam pembentukan pendapatan daerah; 
5. Melihat pertumbuhan/perkembangan perolehan pendapatan dan pengeluaran yang dilakukan selama periode waktu tertentu.

1. Rasio Kemandirian

Kemandirian keuangan daerah yang dimaksud dalam penelitian ini adalah kemapuan suatu daerah untuk membiayai sendiri kegiatan pemerintahan, pembangunan dan pelayanan kepada masyarakat daerahnya (Halim,2002).

2. Rasio Efektivitas

Rasio efektivitas menggambarkan kemampuan pemerintah daerah dalam merealisasikan PAD yang direncanakan dibandingkan dengan target PAD yang ditetapkan (Halim,2002).

3. Rasio Efisiensi

Rasio efisiensi adalah rasio yang menggambarkan perbandingan antara realisasi pengeluaran (belanja daerah) dengan realisasi pendapatan daerah. Rasio efisiensi (Hamzah,2006).

\section{Analisis Kemampuan Keuangan Daerah}

Adapun elastisitas adalah rasio pertumbuhan PAD dengan pertumbuhan PDRB. Rasio ini bertujuan melihat sensitivitas atau elastisitas PAD terhadap perkembangan ekonomi suatu daerah. Sedangkan share merupakan rasio PAD terhadap belanja rutin dan belanja pembangunan daerah. Rasio ini mengukur seberapa jauh kemampuan daerah membiayai kegiatan rutin dan kegiatan pembangunan. Rasio ini dapat digunakan untuk melihat kapasitas kemampuan keuangan daerah. dan growth merupakan angka pertumbuhan PAD tahun i dari tahun i-1.

Pemetaan dan analisis kemampuan keuangan daerah dengan metode kuadran yang dimaksud metode kuadran adalah salah satu cara menampilkan peta kemampuan keuangan daerah. Masing-masing kuadran ditentukan oleh besaran nilai growth dan share. Dengan nilai growth dan share maka dapat diketahui posisinya (pada kuadran berapa).

\section{Metodologi Penelitian}

\section{Teknik Analisis Data}

Analisa data yang digunakan pada penelitian ini melalui tahap tahap sebagai berikut:

1. Menghitung rasio kemandirian berdasarkan APBD. 


$$
\text { Rasio Kemandirian }=\frac{\text { Pendapatan Asli Daerah }(P A D)}{\text { Total Pendapatan Daerah }} \times 100 \%
$$

2. Menghitung rasio efektivitas berdasarkan APBD.

$$
\text { Rasio Efektivitas } \frac{\text { Realisasi Penerimaan PAD }}{\text { Target Penerimaan PAD }} \times 100 \%
$$

3. Menghitung rasio efisiensi berdasarkan APBD.

$$
\text { Rasio Efisiensi }=\frac{\text { Realisasi Belanja Daerah }}{\text { Realisasi Pendapatan Daerah }} \times 100 \%
$$

4. Menghitung Share berdasarkan APBD.

$$
\text { Share }=\frac{P A D}{\text { Total Belanja }} \times 100 \%
$$

5. Menghitung Growth berdasarkan APBD

$$
\text { Growth }=\frac{P A D i}{P A D I-1} \times 100 \%
$$

Peta Kemampuan Keuangan

Berdasarkan Metode Kuadran Rata-rata Growth (\%)

\begin{tabular}{|l|l|}
\hline Kuadran II & Kuadran I \\
share: & share : \\
Rendah & Tinggi \\
Growth: & Growth : \\
Tinggi \\
\hline Tinggi
\end{tabular}

Sumber : Bappenas, 2003. 
Klasifikasi Status Kemampuan Keuangan Daerah

Berdasarkan Metode Kuadran

\begin{tabular}{|c|l|}
\hline KUADRAN & \multicolumn{1}{|c|}{ KONDISI } \\
\hline I & $\begin{array}{l}\text { Kondisi paling ideal. PAD mengambil peran besar dalam } \\
\text { Total Belanja dan daerah mempunyai kemampuan } \\
\text { mengembangkan potensi lokal. Kondisi ini ditunjukkan } \\
\text { dengan besarnya nilai Share dan Growth yang tinggi. }\end{array}$ \\
\hline II & $\begin{array}{l}\text { Kondisi ini belum ideal, tetapi daerah mempunyai } \\
\text { pegembangan potensi lokal, sehingga PAD berpeluang } \\
\text { memiliki peran besar dalam Total Belanja. Sumbangan }\end{array}$ \\
& $\begin{array}{l}\text { PAD terhadap Total Belanja masih rendah namun } \\
\text { pertumbuhan (Growth) PAD tinggi. }\end{array}$ \\
\hline III & $\begin{array}{l}\text { Kondisi ini juga belum ideal. Peran PAD yang besar } \\
\text { dalam Total Belanja mempunyai peluang yang kecil } \\
\text { karena pertumbuhan PADnya kecil. Sumbangan PAD } \\
\text { terhadap Total Belanja tinggi, namun pertumbuhan PAD } \\
\text { rendah. }\end{array}$ \\
\hline Kondisi ini paling buruk. Peran PAD belum mengambil \\
peran yang besar dalam Total Belanja, dan daerah belum \\
mempunyai kemampuan mengembangkan potensi lokal. \\
Sumbangan PAD terhadap Total Belanja dan \\
pertumbuhan PAD terhadap Total Belanja dan \\
pertumbuhan PAD rendah.
\end{tabular}

Sumber : Bappenas, 2003.

\section{Hasil dan Pembahasan}

\section{Rasio Kemandirian}

$$
\text { Rasio Kemandirian }=\frac{\text { Pendapatan Asli Daerah }(P A D)}{\text { Total Pendapatan Daerah }} \times 100 \%
$$

Tabel 4.1: rasio kemandirian kabupaten pesawaran 2010-2014

\begin{tabular}{|c|c|c|c|c|}
\hline $\begin{array}{c}\text { Tahun } \\
\text { Anggara } \\
\text { n }\end{array}$ & $\begin{array}{c}\text { Realisasi } \\
\text { PAD }\end{array}$ & $\begin{array}{c}\text { Total } \\
\text { Pendapatan } \\
\text { Daerah }\end{array}$ & $\begin{array}{c}\text { Rasio } \\
\text { Kemandiria } \\
\text { n }\end{array}$ & $\begin{array}{c}\text { Pola } \\
\text { Hubunga } \\
\text { n }\end{array}$ \\
\hline 2010 & $\begin{array}{c}13.229 .969 .82 \\
\mathbf{5}\end{array}$ & $\begin{array}{c}\mathbf{5 1 3 . 5 6 9 . 1 7 2 . 0 7} \\
\mathbf{1}\end{array}$ & $\mathbf{2 , 5 8 \%}$ & Instruktif \\
\hline 2011 & $\mathbf{1 7 . 9 1 6 . 4 2 5 . 8 7}$ & $\mathbf{6 2 8 . 5 3 7 . 8 1 7 . 4 0}$ & $\mathbf{2 , 8 5 \%}$ & Instruktif \\
& $\mathbf{1}$ & $\mathbf{2}$ & & \\
\hline
\end{tabular}




\begin{tabular}{|l|l|l|l|l|}
\hline 2012 & 25.710 .883 .650 & 676.345 .193 .403 & $\mathbf{3 , 8 0 \%}$ & Instruktif \\
\hline 2013 & $\mathbf{1 8 . 1 0 7 . 0 0 0 . 0 0 0}$ & $\mathbf{7 4 1 . 1 8 8 . 0 0 0 . 0 0 0}$ & $\mathbf{2 , 4 4 \%}$ & Instruktif \\
\hline 2014 & $\mathbf{3 0 . 3 2 5 . 1 0 2 . 6 1 6}$ & $\mathbf{9 0 2 . 0 0 3 . 7 3 0 . 9 0 8}$ & $\mathbf{3 , 3 6 \%}$ & Instruktif \\
\hline \multicolumn{3}{|c|}{ Rata-rata rasio kemandirian } & $\mathbf{3 , 0 1 \%}$ & Instruktif \\
\hline
\end{tabular}

Berdasarkan hasil analisa diatas, dapat dilihat, Rasio kemandirian Kabupaten Pesawaran tahun anggaran 2010 sampai dengan tahun 2014 cenderung mengalami fluktuasi dimana terjadi kenaikan dan penurunan antara Rasio Kemandirian tahun 2010 sampai dengan tahun 2014. Dari hasil analisa diatas dapat dihitung besarnya Rasio kemandirian pada tahun 2010 menghasilkan angka sebesar 2.58\%, pada tahun 2011 menghasilkan angka sebesar 2,85\%. tahun 2012 menghasilkan angka sebesar 3,80\%. Rasio kemandirian pada tahun 2013 menghasilkan angka sebesar 2,44\%. Rasio kemandirian pada tahun 2014 menghasilkan angka sebesar 3,36\%. Dimana realisasi PAD sebesar Rp 30.325.102.616 dibagi dengan total pendapatan sebesar Rp 902.003.730.908.

Jadi rata-rata Rasio kemandirian Kabupaten Pesawaran selama 5 tahun sebesar 3,01\%. Dengan jumlah rasio tersebut, menurut pola hubungan tingkat kemandirian daerah tingkat kemandirian daerah Kabupaten Pesawaran dikatakan sangat rendah sekali, sehingga masuk kedalam kategori pola hubungan instruktif, yaitu berkisar antara 0\%-25\%. Dalam pola hubungan instruktif, peran pemerintah pusat lebih dominan terhadap kemandirian daerah.

Jika dilihat dari tabel, pendapatan asli daerah Kabupaten Pesawaran lebih cenderung meningkat begitu juga dengan total pendapatan dari pemerintah pusat. Sehingga dapat dikatakan pemerintah daerah Kabupaten Pesawaran masih sangat tergantung dengan pemerintah pusat. Hal ini menunjukan bahwa pemerintah Kabupaten Pesawaran belum optimal dalam menggali potensi yang ada di daerah baik berupa pajak, retribusi yang dapat meningkatkan pendapatan asli daerah, sehingga tingkat ketergantungan terhadap pemerintah pusat semakin berkurang.

\section{Rasio Efektivitas}

$$
\text { Rasio Efektivitas } \frac{\text { Realisasi Penerimaan PAD }}{\text { Target Penerimaan PAD }} \times 100 \%
$$


Analisis Rasio Keuangan Anggaran Pendapatan dan Belanja Daerah ..(Herry Goenawan Soedarsa).

Tabel 4.2: Rasio efektivitas kabupaten pesawaran tahun 2010-2014.

\begin{tabular}{|c|c|c|c|c|}
\hline $\begin{array}{c}\text { Tahun } \\
\text { Anggaran }\end{array}$ & $\begin{array}{c}\text { Realisasi } \\
\text { Penerimaan } \\
\text { PAD }\end{array}$ & $\begin{array}{c}\text { Target } \\
\text { Penerimaan } \\
\text { PAD }\end{array}$ & $\begin{array}{c}\text { Rasio } \\
\text { Efektivitas }\end{array}$ & $\begin{array}{c}\text { Kriteria } \\
\text { Rasio } \\
\text { Efektivitas }\end{array}$ \\
\hline 2010 & 13.229.969.825 & 5.577.050.000 & $237,22 \%$ & $\begin{array}{c}\text { Sangat } \\
\text { efektif }\end{array}$ \\
\hline 2011 & 17.916 .425 .871 & 8.486 .365 .000 & $211,12 \%$ & $\begin{array}{l}\text { Sangat } \\
\text { efektif }\end{array}$ \\
\hline 2012 & 25.710.883.650 & 14.715.956.000 & $174,71 \%$ & $\begin{array}{l}\text { Sangat } \\
\text { efektif }\end{array}$ \\
\hline 2013 & 18.107.000.000 & 18.106.308.035 & $100,00 \%$ & efektif \\
\hline 2014 & 30.325.102.616 & 31.569.771.251 & $96,06 \%$ & $\begin{array}{l}\text { Cukup } \\
\text { efektif }\end{array}$ \\
\hline \multicolumn{3}{|c|}{ Rata-rata rasio efektivitas } & $163,822 \%$ & $\begin{array}{c}\text { Sangat } \\
\text { efektif }\end{array}$ \\
\hline
\end{tabular}

Dilihat dari data yang ada dalam tabel dan grafik, rasio efektivitas Kabupaten Pesawaran tahun anggaran 2010 sampai 2014, rasio efektivitas tergolong tinggi pada 2010 akan tetapi terus terjadi penurunan sampai 2014. Hasil perhitungan realisasi penerimaan PAD terhadap target penerimaan PAD menunjukan bahwa pada tahun rasio efektivitas menghasilkan angka sebesar 237,22\%. Tahun 2011 rasio efektivitas menghasilkan angka sebesar $211,12 \%$. Tahun 2012 rasio efektivitas sebesar $174,71 \%$. Tahun 2013 rasio efektivitas sebesar 100,00\%. Tahun 2014 rasio efektivitas sebesar 96,06\%. Jika dilihat dari tabel hasil perhitungan dan grafik keseluruhan rasio efektivitas Kabupaten Pesawaran selama lima tahun, dapat disimpulkan bahwa rasio efektivitas semua periode dikatakan sangat efektif, kecuali tahun 2014 yang tingkat efektivitasnya termasuk kedalam kriteria cukup efektif. Rata-rata rasio efektivitas Kabupaten Pesawaran selama 5 tahun sebesar 163,822\%. Dengan jumlah tersebut, kriteria rasio efektivitas Kabupaten Pesawaran masuk kedalam kategori sangat efektif. Hal ini menunjukan bahwa perbandingan antara target dan realisasi pendapatan asli daerah (PAD) memiliki kemampuan yang baik dalam memobilisasi penerimaan pendapatan sesuai dengan yang ditargetkan.

\section{Rasio Efisiensi}

$$
\text { Rasio Efisiensi }=\frac{\text { Realisasi Belanja Daerah }}{\text { Realisasi Pendapatan Daerah }} \times 100 \%
$$


Tabel 4.3: Rasio efisiensi kabupaten pesawaran tahun 2010-2014.

\begin{tabular}{|c|c|c|c|c|}
\hline $\begin{array}{c}\text { Tahun } \\
\text { Anggaran }\end{array}$ & $\begin{array}{c}\text { Realisasi Belanja } \\
\text { Daerah }\end{array}$ & $\begin{array}{c}\text { Realisasi } \\
\text { Pendapatan } \\
\text { Daerah }\end{array}$ & $\begin{array}{c}\text { Rasio } \\
\text { Efisiensi }\end{array}$ & $\begin{array}{c}\text { Kriteria } \\
\text { Rasio } \\
\text { Efisiensi }\end{array}$ \\
\hline 2010 & $\mathbf{6 0 4 . 2 6 1 . 8 7 7 . 8 5 0}$ & $\mathbf{5 1 3 . 5 6 9 . 1 7 2 . 0 7 1}$ & $\mathbf{1 1 7 , 6 6 \%}$ & $\begin{array}{c}\text { Tidak } \\
\text { efisien }\end{array}$ \\
\hline 2011 & $\mathbf{5 7 0 . 3 7 3 . 4 2 4 . 1 3 5}$ & $\mathbf{6 2 8 . 5 3 7 . 8 1 7 . 4 0 2}$ & $\mathbf{9 0 , 7 5 \%}$ & $\begin{array}{c}\text { Kurang } \\
\text { efisien }\end{array}$ \\
\hline 2012 & $\mathbf{6 7 2 . 3 9 0 . 7 0 5 . 4 3 7}$ & $\mathbf{6 7 6 . 3 4 5 . 1 9 3 . 4 0 3}$ & $\mathbf{9 9 , 4 2 \%}$ & $\begin{array}{c}\text { Kurang } \\
\text { efisien }\end{array}$ \\
\hline 2013 & $\mathbf{5 2 5 . 8 8 4 . 7 7 3 . 6 6 6}$ & $\mathbf{7 4 1 . 1 8 8 . 0 0 0 . 0 0 0}$ & $\mathbf{7 0 , 9 5 \%}$ & Efisien \\
\hline 2014 & $\mathbf{1 . 0 2 0 . 2 1 5 . 3 3 0 . 5 8 9}$ & $\mathbf{9 0 2 . 0 0 3 . 7 3 0 . 9 0 8}$ & $\mathbf{1 1 3 , 1 1 \%}$ & $\begin{array}{c}\text { Tidak } \\
\text { efisien }\end{array}$ \\
\hline & Rata-rata rasio efisiensi & $\mathbf{9 8 , 3 8 \%}$ & $\begin{array}{c}\text { Kurang } \\
\text { efisien }\end{array}$ \\
\hline
\end{tabular}

Dilihat dari data yang ada dalam tabel dan grafik, rasio efisiensi Kabupaten Pesawaran tahun anggaran 2010 sampai 2014, rasio efisiensi Kabupaten Pesawaran mengalami fluktuasi dimana terjadi peningkatan dan penurunan. rasio efisiensi pada Tahun 2010 rasio efisiensi menghasilkan angka sebesar 117,66\%. Tahun 2011 rasio efisiensi menghasilkan angka sebesar 90,75\%. Tahun 2012 rasio efisiensi menghasilkan angka sebesar 99,42\%. Tahun 2013 rasio efisiensi menghasilkan angka sebesar 70,95\%. Tahun 2014 rasio efisiensi menghasilkan angka sebesar $113,11 \%$.

Dengan jumlah tersebut, rata-rata rasio efisiensi Kabupaten Pesawaran adalah sebesar 98,38\%. Menurut kriteria efisiensi Kabupaten Pesawaran masuk kedalam kriteria kurang efisien. Semakin kecil nilai rasio efisiensi maka semakin baik kinerja pemerintah dalam membelanjakan pendapatanya sehingga belanja tersebut dapat berkontribusi dalam peningkatan pendapatan daerah. Kabupaten Pesawaran masih harus mengalokasikan belanja yang berkontribusi besar dalam pendapatan daerahnya. Serta melakukan pengawasan terhadap kemungkinan terjadinya penyimpangan dan pemborosan dalam anggaran belanja daerah sehingga rasio efisiensi kabupaten pesawaran dapat lebih baik lagi.

Share

$$
\text { Share }=\frac{P A D}{\text { Total Belanja }} \times 100 \%
$$


Analisis Rasio Keuangan Anggaran Pendapatan dan Belanja Daerah ..(Herry Goenawan Soedarsa).

Tabel 4.4: Share kabupaten pesawaran tahun 2010-2014.

\begin{tabular}{|c|c|c|c|}
\hline $\begin{array}{c}\text { Tahun } \\
\text { Anggaran }\end{array}$ & PAD & Total Belanja & Nilai \\
\hline 2010 & 13.229 .969 .825 & 604.261 .877 .850 & $2,19 \%$ \\
\hline 2011 & 17.916 .425 .871 & 570.373 .424 .135 & $3,14 \%$ \\
\hline 2012 & 25.710 .883 .650 & 672.390 .705 .437 & $3,82 \%$ \\
\hline 2013 & 18.107 .000 .000 & 525.884 .773 .666 & $3,44 \%$ \\
\hline 2014 & 30.325 .102 .616 & 1.020 .215 .330 .589 & $2,97 \%$ \\
\hline \multicolumn{3}{|c|}{ Rata-rata share } & $3,11 \%$ \\
\hline
\end{tabular}

Dilihat dari data yang ada dalam tabel, Share Kabupaten Pesawaran tahun anggaran 2010 sampai 2014, Kabupaten Pesawaran mengalami fluktuasi dimana terjadi peningkatan dan penurunan. Share pada Tahun 2010 Share menghasilkan angka sebesar 2,19\%. Tahun 2011 Share menghasilkan angka sebesar 3,14\%. Tahun 2012 Share menghasilkan angka sebesar 3,82\%. Tahun 2013 Share menghasilkan angka sebesar 3,44\%. Tahun 2014 Share menghasilkan angka sebesar 2,97\%.

Dari perhitungan Share selama lima tahun maka diperoleh rata-rata Share sebesar 3,11\%. Hal ini menunjukan bahwa sumbangan PAD terhadap total belanja masih rendah artinya pemerintah daerah masih harus menggali potensi yang dimilikinya secara lebih maksimal sehingga dapat meningkatkan PAD yang berperan besar dalam APBD.

Growth

$$
\text { Growth }=\frac{P A D i}{P A D I-1} \times 100 \%
$$

Tabel 4.5: Growth kabupaten pesawaran tahun 2010-2014.

\begin{tabular}{|c|c|c|}
\hline $\begin{array}{c}\text { Tahun } \\
\text { Anggaran }\end{array}$ & PAD & Growth \\
\hline 2010 & $\mathbf{1 3 . 2 2 9 . 9 6 9 . 8 2 5}$ & - \\
\hline 2011 & 17.916 .425 .871 & $\mathbf{3 8 2 , 3 0 2 \%}$ \\
\hline 2012 & $\mathbf{2 5 . 7 1 0 . 8 8 3 . 6 5 0}$ & $\mathbf{3 2 9 , 8 6 1 \%}$ \\
\hline 2013 & $\mathbf{1 8 . 1 0 7 . 0 0 0 . 0 0 0}$ & $\mathbf{2 3 8 , 1 2 8 \%}$ \\
\hline 2014 & $\mathbf{3 0 . 3 2 5 . 1 0 2 . 6 1 6}$ & $\mathbf{2 4 8 , 1 9 8 \%}$ \\
\hline \multicolumn{2}{|c|}{ Rata-rata Growth } & $\mathbf{2 9 9 , 6 2 2 \%}$ \\
\hline
\end{tabular}


Dilihat dari data yang ada dalam tabel, Growth Kabupaten Pesawaran tahun anggaran 2010 sampai 2014, mengalami fluktuasi dimana terjadi peningkatan dan penurunan. Pada Tahun 2011 Growth menghasilkan angka sebesar 382,302\%. Tahun 2012 Growth menghasilkan angka sebesar 329,861\%. Tahun 2013 Growth menghasilkan angka sebesar 238,128\%. Tahun 2014 Growth menghasilkan angka sebesar 248,198\%.

Dari perhitungan Share dan Growth anggaran pendapatan dan belanja daerah Kabupaten Pesawaran tahun 2010 sampai 2014, maka diperoleh ratarata Share sebesar 3,11\%. dan Growth sebesar 299,622\%. Kemudian pemetaan kemampuan keuangan daerah berdasarkan metode kuadran posisi Kabupaten Pesawaran Berada pada kuadran II, kondisi ini belum ideal, hal ini dapat dilihat dari Sumbangan PAD terhadap total belanja (Share) masih rendah namun pertumbuhan (Growth) PAD tinggi. Ini menunjukan bahwa daerah mempunyai potensi untuk meningkatkan peran PAD terhadap total belanja.

Dari penjelasan diatas dapat disimpulkan bahwa pemerintah daerah Kabupaten Pesawaran masih dapat menggali potensi daerahnya secara maksimal, sehingga meningkatkan PAD yang berperan besar dalam anggaran pendapatan dan belanja daerah.

\section{Kesimpulan dan Saran \\ Kesimpulan}

Berdasarkan pembahasan yang telah saya lakukan terdapat beberapa

kesimpulan sebagai berikut:

1. Rasio Kemandirian daerah berada pada pola hubungan instruktif, ratarata rasio kemandirian Kabupaten Pesawaran tahun anggaran 2010 sampai dengan 2014 mendapat angka sebesar 3,01\%.

2. Rasio Efektivitas Kabupaten Pesawaran masuk kedalam kriteria sangat efektif rata-rata rasio dengan angka sebesar 163,822\%.

3. rasio efisiensi selama 5 tahun masuk kedalam kriteria kurang efisien dengan rata-rata rasio mendapat angka sebesar 98,38\%. Hal ini menunjukkan bahwa perbandingan belanja terhadap pendapatan belum efisien.

4. Share dan Growth anggaran pendapatan dan belanja daerah Kabupaten Pesawaran tahun 2010 sampai 2014, diperoleh angka Share sebesar 3,11\%. dan Growth sebesar 299,622\%. pemetaan kemampuan keuangan daerah berdasarkan metode kuadran posisi Kabupaten Pesawaran berada pada kuadran II, dapat dilihat dari Sumbangan PAD terhadap total belanja (Share) masih rendah namun pertumbuhan (Growth) PAD tinggi. 


\section{Saran}

Dari hasil perhitungan dan pembahasan, maka saran yang diberikan penulis adalah sebagai berikut:

1. Untuk meningkatkan kemandirian keuangan daerah pemerintah Kabupaten Pesawaran diminta untuk menggali sumber-sumber yang berpotensi dalam meningkatkan pendapatan daerah yang belum tersentuh dan melakukan upaya pengawasan yang efektif terhadap pemungutan pajak dan retribusi daerah.

2. Upaya dalam meningkatkan efisiensi keuangan daerah dapat dilakukan dengan melakukan pembelanjaan daerah sesuai dengan kebutuhan daerah dan melakukan pengawasan terhadap pembelanjaan daerah untuk menghindari penyimpangan.

3. Sedangkan untuk elastisitas PAD pemerintah daerah Kabupaten Pesawaran masih harus menggali lebih maksimal potensi yang dimiliki daerahnya, kabupaten pesawaran meiliki destinasi wisata pantai yang indah apabila hal ini dikelola dengan baik tentunya akan meningkatkan pendapatan daerah dari sektor pariwisata, sehingga PAD berperan lebih besar dalam APBD.

\section{DAFTAR PUSTAKA}

BAPPENAS. 2003. Peta Kemampuan Keuangan Provinsi Dalam Era

Otonomi

Daerah. Direktorat Pengembangan Otonomi Daerah.

Budiarjo, Koswara. (2001:169), World bank, good governance, (dalam LAN:2000:5), "the way state power used in managing economic and society". https://adilesmana.wordpress.com/2010/08/17/pertanggungjaw aban-publik-dan-legitimasipemerintahan/?_e_pi_=7\%2cPAGE_ID10\%2c2798002737 Pada 5 September 2015 jam 11.30 WIB.

Bastian, 2001. Indikator-Indikator Keberhasilan Pengelolaan Keuangan Darah 1999-2000. Universitas Gadjah Mada. Yogyakarta.

DeddyK, Peta Kemampuan Keuangan Provinsi dalam Era Otonomi Daerah. Jurnal Akuntansi. 
Departemen Dalam Negeri. Keputusan Menteri Dalam Negeri Nomor 690.900.327.1996 tentang Pedoman Penilaian dan Kinerja Keuangan.

Herry, Avrina. 2014. Analisis Kinerja Keuangan Pemerintah Kabupaten/Kota Se-Provinsi Lampung. Jurnal Akuntansi \& Keuangan, Vol.5, No.2, 59-70.

Halim, 2002. Akuntansi Sektor Publik. Akuntansi Keuangan Daerah. Salemba Empat. Jakarta.

Hamzah, Hery. 2006. Pengaruh Belanja dan Pendapatan terhadap pertumbuhan Ekonomi, Kemiskinan dan Pengangguran. Jatim. Konferensi Penelitian.

Mahsun, Moh., Firma Sulistyowati \& Heribertus Andre Purwanugraha. (2011).Akuntansi Sektor Publik, Yogyakarta: BPFE.

Mahmudi, (2010). Analisis Laporan Keuangan Pemerintah Daerah: Panduan Bagi Eksekutif, Legislatif, dan Masyarakat Dalam Pengambilan Keputusan Ekonomi, Sosial, dan Politik, Edisi 2, Yogyakarta: UPP STIM YKPN.

Mahmudi, (2011). Akuntansi Sektor Publik, Yogyakarta: UII Press.

Mardiasmo. (2010). Akuntansi Sektor Publik dan Good Governance, bahan paparan pada Seminar Nasional Akuntansi Sektor Publik yang diselenggarakan oleh Fakultas Ekonomi, Universitas Islam Indonesia, 13 Maret 2010.

Mardiasmo. 2002. Otonomi dan Manajemen Keuangan Daerah. Andi. Yogyakarta.

Pramono, 2011. Analisis Rasio Keuangan Untuk Menilai Kinerja Keuangan Pemerintah Daerah Kota Surakarta. Jurnal Skripsi. STIE AMA Salatiga.

Peraturan Menteri Dalam Negeri Nomor 21 Tahun 2011, tentang struktur atau komponen APBD.

Peraturan Menteri Dalam Negeri Nomor 37 Tahun 2014, tentang pedoman penyusunan APBD tahun 2015. 
Analisis Rasio Keuangan Anggaran Pendapatan dan Belanja Daerah ...(Herry Goenawan Soedarsa).

Peraturan Pemerintah Republik Indonesia No 71 tahun 2010 tentang Standar Akuntansi Pemerintahan.

Peraturan Pemerintah Republik Indonesia No 65 tahun 2001 tentang Pajak Daerah.

Peraturan Pemerintah Republik Indonesia No 66 tahun 2001 tentang Retribusi Daerah.

PPH, 25, 29, 21. Tentang pajak penghasilan.

Syamsi, ibnu. 1986. Pokok-Pokok Kebijaksanaan, Perencanaan Pemrograman, Dan Penganggaran Pembangunan Tingkat Nasional. CV. Rajawali. Jakarta.

Sugiyono. 2012. Analisis Deskriptif dalam Metode Penelitian Kualitatif. Penerbit Alfabeta. Jakarta.

Teori sinyal, Jama'an. (2008). http://ekonomi.kabo.biz/2011/07/teorisinyal.html Pada 11 Januari 2016 Jam 11.30 WIB.

Undang-Undang RI No. 5 tahun 1979 tanggungjawab penyelenggara negara.

Undang-Undang RI No. 32 tahun 2004 tentang Pemerintah Daerah.

Undang-Undang RI No. 12 tahun 2008 tentang dana perimbangan antara pemerintah pusat dan daerah.

Undang-Undang RI No. 28 Tahun 2009 Tentang Pajak Daerah dan Retribusi Daerah.

Undang-Undang RI No. 33 Tahun 2004 Tentang Perimbangan Keuangan Pusat dan Daerah.

Ulum, Ihyahul. (2009). Audit Sektor Publik, Jakarta: PT Bumi Aksara.

Yuliana, 2013. Analisis Kinerja Anggaran Pendapatan Dan Belanja (Apbd) Ditinjau Dari Rasio Keuangan Kabupaten Sragen. Skripsi. Universitas Muhammadiyah Surakarta. 